\title{
Insights into Neonatal Oral Feeding through the Salivary Transcriptome
}

\author{
Jill L. Maron \\ Division of Newborn Medicine, Mother Infant Research Institute at Tufts Medical Center, \\ Floating Hospital for Children at Tufts Medical Center, 800 Washington Street, P.O. Box 394, Boston, MA 02111, USA \\ Correspondence should be addressed to Jill L. Maron, jmaron@tuftsmedicalcenter.org
}

Received 2 April 2012; Accepted 21 May 2012

Academic Editor: Chantal Lau

Copyright ( 2012 Jill L. Maron. This is an open access article distributed under the Creative Commons Attribution License, which permits unrestricted use, distribution, and reproduction in any medium, provided the original work is properly cited.

\begin{abstract}
Background. The development of safe and effective oral feeding skills in the newborn is complex and may be associated with significant morbidities. Our understanding of neonatal oral feeding maturation at the molecular level is limited, providing an opportunity to utilize emerging molecular techniques to accurately assess neonatal oral feeding skills. Objective. To identify key regulatory genes in neonatal saliva involved in successful oral feeding. Methods. Previously, our laboratory identified 9,286 genes in saliva that statistically significantly altered their gene expression as premature newborns gained advanced oral feeding skills. In this report, genes previously identified underwent an updated and targeted pathway analysis with Ingenuity Pathway Analysis (IPA) to identify potential candidate genes involved in successful oral feeding. Genes were considered if they were in the five most significantly up- and down-regulated physiological pathways and were associated with the keywords "feeding", "digestion" and "development". Results. There were 2,186 genes that met criteria. Pathways associated with feeding behavior, cranial nerve development, and the development of the nervous, skeletal, and muscular systems were highlighted. Discussion. These data provide important insights into the biological processes involved in oral feeding in the newborn at a molecular level and identify novel pathways associated with successful oral feeding.
\end{abstract}

\section{Introduction}

The vast majority of infants admitted to the neonatal intensive care unit (NICU) must acquire the skills for successful oral feeding prior to discharge. For the preterm infant, this complex task is not without risks. Successful oral feeding involves the maturation and integration of the nervous, sensory, muscular, and digestive systems. Failed oral feeding trials can result in an array of morbidities including choking, aspiration, bradycardia, desaturations, feeding aversions, and both short- and long-term impaired neurological outcomes [1-4]. Further, there is a subset of term infants who have either delayed or unsafe oral feeding skills, resulting in prolonged hospitalization and/or surgical placement of a gastric tube for administration of enteral nutrition. Despite the fact that the vast majority of infants in the NICU are at risk for these morbidities, research on neonatal feeding is relatively scarce compared to other complications of prematurity, such as bronchopulmonary dysplasia [5] and necrotizing enterocolitis [6], that almost exclusively affect a much smaller percentage of infants born at $<32$ weeks' gestation and/or at extremely low or very low birthweights [7].

Currently, newborns rely on the interpretation of subjective feeding cues by their caregivers to determine when it is safe to orally feed $[8,9]$. Our understanding of the complexities of oral feeding maturation in the developing infant at the molecular level is largely unknown. Thus, there is an opportunity to incorporate emerging molecular techniques with conventional clinical approaches to improve our understanding of the complexities of oral feeding, and to develop objective diagnostic assays to accurately assess neonatal oral feeding skills.

Previously, our laboratory described the enormous amount of real-time global developmental information available from premature infants through noninvasive salivary gene expression analyses [10]. Although in the initial study we did not specifically target gene transcripts involved in oral 
TABle 1: Pertinent clinical information of subjects.

\begin{tabular}{lcccl}
\hline Subject & Gender & $\begin{array}{c}\text { Gestational age } \\
\text { (weeks) }\end{array}$ & Birthweight (g) & Medical complications \\
\hline 1 & Male & 29 & 1389 & $\begin{array}{l}\text { Respiratory distress syndrome (RDS), apnea, anemia, and hyperbiliru- } \\
\text { binemia }\end{array}$ \\
2 & Female & $283 / 7$ & 942 & $\begin{array}{l}\text { RDS, hyperbilirubinemia, anemia, and apnea } \\
\text { RDS, hyperbilirubinemia, apnea, anemia, and retinopathy of prematurity } \\
\text { (stage 2, zone 2) }\end{array}$ \\
4 & Male & $283 / 7$ & 1123 & RDS, hyperbilirubinemia, apnea, and anemia \\
5 & Female & 32 & 1683 & RDS, hyperbilirubinemia, apnea, and anemia \\
\hline
\end{tabular}

feeding, this original discovery-driven research identified key regulatory genes, as well as novel pathways, associated with oral feeding in the preterm infant.

In the two years since this initial work was published, our understanding of the physiological functions of the genes initially identified continues to improve. Newly published reports on gene functions and their association with oral feeding have emerged. This has prompted a targeted reexamination of the data to identify previously unrecognized genes in neonatal saliva that may correlate to oral feeding success. Identifying these genes and their associated biological and physiological pathways may not only lead to objective, noninvasive salivary biomarkers that accurately predict oral feeding readiness, but may also highlight aberrant developmental pathways that correlate with pathological feeding behavior in the newborn.

\section{Materials and Methods}

This study was approved by the Tufts Medical Center Institutional Review Board. Parental consent was obtained for all enrolled subjects $(n=5)$. Salivary samples were collected and processed as previously described [10]. Gestational age at birth of the subjects ranged from 28 to 32 weeks. There were two females and three males in this data set. Pertinent clinical information, including medical complications, of each subject can be found in Table 1. Salivary samples were collected from each subject from the following time points: (1) no feeds; (2) partial gastric feeds; (3) full gastric feeds; (4) some oral feeds; (5) advanced oral feeds. Salivary RNA was extracted, amplified, and hybridized onto the Affymetrix HG U133 2.0 Plus gene expression arrays.

2.1. Analysis. All arrays $(n=25)$ underwent normalization and bioinformatic analysis as previously described [10]. Genes that were shown to statistically significantly alter their gene expression over time at a false discovery rate $P$ value of $<0.05$ were identified $(n=9,286)$. There were 5,764 upregulated and 3,522 down-regulated genes that met statistical criteria and altered their expression profile as the subjects matured through the feeding stages. For the purpose of this study, the up- and down-regulated gene lists were uploaded into the newest version of Ingenuity Pathway Analysis (IPA Content version: 11904312, release date 12-15-2011). IPA then performed a functional analysis of the gene lists with a right-tailed Fisher's exact test to calculate a $P$ value determining the probability that each biological function assigned to that data set was due to chance alone. This analysis provided a comprehensive biological assessment of the gene-gene interactions, gene functions and gene regulation in our data sets.

In order to provide a targeted analysis of genes most likely to be related to oral feeding skills, genes that clustered into statistically significantly biological pathways by IPA were only considered if they met the following criteria: (a) they were in the five most statistically significantly up- or down-regulated physiological pathways; (b) they were associated with the key terms "feeding," "digestion," and/or "development" in the IPA analysis. Thus, genes had to statistically significantly alter their gene expression over time, and be identified by IPA as significantly clustering into pathways believed to be associated with oral feeding skills to be considered in this analysis. Genes that met these criteria were further reviewed by the author with the use of IPA, PubMed, and EntrezGene to better understand their functions and possible roles in neonatal oral feeding.

\section{Results and Discussion}

From 2010 when the data was initially published until present, the functions of $4 \%$ of the genes in the original data sets have been modified. As such, those genes are no longer considered valid for previously identified biological functions, canonical pathways, or networks. This recategorization of genes is a direct result of emerging literature and an improved understanding of gene function, gene-gene interaction, and gene regulation. Although it is common for gene expression analyses to change over time, the slight difference in gene analysis from this data set has allowed for the identification of genes not previously known to be associated with neonatal oral feeding. The most significant physiologic pathways identified in this analysis highlight the complexity of oral feeding and involve not only tissue and nervous system development, but key pathways involved in feeding behavior. The five most statistically significantly upregulated pathways were "behavior" $\left(10^{-10}<P<10^{-2}\right)$, "nervous system development" $\left(10^{-9}<P<10^{-2}\right)$, "tissue development" $\left(10^{-7}<P<10^{-2}\right)$, "embryonic development" $\left(10^{-7}<P<10^{-2}\right)$, and "organ development" $\left(10^{-7}<P<\right.$ $\left.10^{-2}\right)$. The five most statistically significantly down-regulated pathways were "hematological system development and 
TABLE 2: Genes involved in feeding behavior $\left(P<10^{-5}\right)$.

\begin{tabular}{|c|c|c|}
\hline Gene & Gene symbol & Relevant biological function \\
\hline $\begin{array}{l}\text { Angiotensin I converting enzyme } \\
\text { (peptidyl-dipeptidase A) } 1\end{array}$ & $\mathrm{ACE}$ & $\begin{array}{l}\text { This gene encodes an enzyme involved in catalyzing the conversion of } \\
\text { angiotensin I into a physiologically active peptide angiotensin II. }\end{array}$ \\
\hline Cholecystokinin A receptor & CCKAR & In the central and peripheral nervous system this receptor regulates satiety. \\
\hline Cannabinoid receptor 1 (brain) & CNR1 & $\begin{array}{l}\text { Animal experiments utilizing receptor antagonists resulted in suppressed food } \\
\text { and water intake with concurrent decreased body weight. }\end{array}$ \\
\hline Corticotropin releasing-hormone & $\mathrm{CRH}$ & $\begin{array}{l}\text { Corticotropin-releasing hormone is secreted by the paraventricular nucleus } \\
(\mathrm{PVN}) \text { of the hypothalamus in response to stress. }\end{array}$ \\
\hline $\begin{array}{l}\text { Corticotropin releasing-hormone } \\
\text { receptor } 1\end{array}$ & CRHR1 & $\begin{array}{l}\text { The encoded protein is essential for the activation of signal transduction } \\
\text { pathways that regulate diverse physiological processes including obesity. }\end{array}$ \\
\hline $\begin{array}{l}\text { Diencephalon/mesencephalon } \\
\text { homeobox } 1\end{array}$ & DMBX1 & $\begin{array}{l}\text { This gene is known to be involved in adult feeding behavior and may play a role } \\
\text { in brain and sensory organ development. }\end{array}$ \\
\hline Free fatty acid receptor 1 & FFAR1 & $\begin{array}{l}\text { The encoded protein is a receptor for medium and long chain free fatty acids } \\
\text { and may be involved in the metabolic regulation of insulin secretion. }\end{array}$ \\
\hline $\begin{array}{l}\text { Glutamate decarboxylase } 2 \text { (pancreatic } \\
\text { islets and brain, } 65 \mathrm{kDa} \text { ) }\end{array}$ & GAD2 & This gene has been shown to be a candidate gene for obesity in humans. \\
\hline Galanin-like peptide & GALP & $\begin{array}{l}\text { This gene is involved in biological processes including hypothalamic regulation } \\
\text { of metabolism. }\end{array}$ \\
\hline Galanin receptor 3 & GALR3 & $\begin{array}{l}\text { The neuropeptide galanin modulates a variety of physiologic processes including } \\
\text { feeding behavior. }\end{array}$ \\
\hline Glucagon & GCG & $\begin{array}{l}\text { Glucagon is a pancreatic hormone that counteracts the glucose-lowering action } \\
\text { of insulin by stimulating glycogenolysis and gluconeogenesis. }\end{array}$ \\
\hline $\begin{array}{l}\text { Growth hormone secretagogue } \\
\text { receptor }\end{array}$ & GHSR & $\begin{array}{l}\text { The encoded protein may play a role in energy homeostasis and regulation of } \\
\text { body weight. }\end{array}$ \\
\hline Glucagon-like peptide 1 receptor & GLP1R & This gene is involved in energy reserve metabolic processes and feeding behavior. \\
\hline $\begin{array}{l}\text { Glutamate receptor, ionotropic, } \\
\text { N-methyl D-aspartate } 2 B\end{array}$ & GRIN2B & $\begin{array}{l}\text { NMDA receptor channel is involved in the activity-dependent increase in the } \\
\text { efficiency of synaptic transmission thought to underlie certain kinds of memory } \\
\text { and learning. }\end{array}$ \\
\hline Hypocretin (orexin) receptor 2 & HCRTR2 & $\begin{array}{l}\text { The protein encoded by this gene is a G protein coupled receptor involved in the } \\
\text { regulation of feeding behavior. }\end{array}$ \\
\hline Histamine receptor $\mathrm{H} 3$ & HRH3 & $\begin{array}{l}\text { This gene encodes an integral membrane protein and can regulate neurotrans- } \\
\text { mitter release. }\end{array}$ \\
\hline $\begin{array}{l}\text { 5-hydroxytryptamine (serotonin) } \\
\text { receptor } 1 \mathrm{~A}, \mathrm{G} \text { protein-coupled }\end{array}$ & HTR1A & Gene has been shown to be involved in control of food intake in obese rats. \\
\hline $\begin{array}{l}5 \text {-hydroxytryptamine (serotonin) } \\
\text { receptor } 2 \mathrm{C}, \mathrm{G} \text { protein-coupled }\end{array}$ & HTR2C & This gene is involved in feeding behavior. \\
\hline Interleukin 1 receptor antagonist & IL1RN & $\begin{array}{l}\text { The protein encoded by this gene is a member of the interleukin } 1 \text { cytokine } \\
\text { family. }\end{array}$ \\
\hline Janus kinase 1 & JAK1 & Knockout mice of this gene exhibit decreased nursing behavior. \\
\hline Junctophilin 1 & JPH1 & This gene is involved in muscle organ development. \\
\hline Lactalbumin, alpha & LALBA & This gene encodes alpha-lactalbumin, a principal protein of milk. \\
\hline Leptin receptor & LEPR & $\begin{array}{l}\text { This protein is a receptor for leptin and is involved in the regulation of fat } \\
\text { metabolism. }\end{array}$ \\
\hline $\begin{array}{l}\text { Melanin-concentrating hormone } \\
\text { receptor } 1\end{array}$ & MCHR1 & The gene is involved in the neuronal regulation of food consumption. \\
\hline NK2 homeobox 1 & NKX2-1 & This gene is involved in brain development and feeding behavior. \\
\hline Neuropeptide Y receptor Y1 & NPY1R & $\begin{array}{l}\text { Neuropeptide Y exhibits a diverse range of important physiologic activities } \\
\text { including regulation of food consumption. }\end{array}$ \\
\hline Neuropeptide Y receptor Y2 & NPY2R & This gene is involved in regulating feeding behavior. \\
\hline $\begin{array}{l}\text { Neurotrophic tyrosine kinase, } \\
\text { receptor, type } 2\end{array}$ & NTRK2 & $\begin{array}{l}\text { This gene is involved in feeding behavior. Mutations in this gene have been } \\
\text { associated with obesity. }\end{array}$ \\
\hline Opioid receptor, kappa 1 & OPRK1 & This gene is involved in regulating behavior. \\
\hline Peroxisomal biogenesis factor 13 & PEX13 & This gene is involved in suckling behavior. \\
\hline POU class 4 homeobox 1 & POU4F1 & This gene is highly expressed in the developing sensory nervous system. \\
\hline
\end{tabular}


TABle 2: Continued.

\begin{tabular}{|c|c|c|}
\hline Gene & Gene symbol & Relevant biological function \\
\hline Prolactin releasing hormone & PRLH & $\begin{array}{l}\text { This gene is involved in feeding behavior and regulates multicellular organism } \\
\text { growth. }\end{array}$ \\
\hline $\begin{array}{l}\text { Prostaglandin E receptor } 3 \text { (subtype } \\
\text { EP3) }\end{array}$ & PTGER3 & $\begin{array}{l}\text { This receptor may have many biological functions, which involve digestion and } \\
\text { the nervous system. }\end{array}$ \\
\hline PTK2 protein tyrosine kinase 2 & PTK2 & $\begin{array}{l}\text { This gene plays a role in glucose response, fat-cell differentiation, and the growth } \\
\text { hormone receptor signaling pathway. }\end{array}$ \\
\hline Peptide YY & PYY & This gene is involved in digestion and feeding behavior. \\
\hline $\begin{array}{l}\text { Solute carrier family } 18 \text { (vesicular } \\
\text { monoamine), member } 2\end{array}$ & SLC18A2 & This gene is involved in glucose homeostasis and response to starvation. \\
\hline $\begin{array}{l}\text { Solute carrier family } 27 \text { (fatty acid } \\
\text { transporter), member } 5\end{array}$ & SLC27A5 & This gene is involved in digestion. \\
\hline Tachykinin receptor 1 & TACR1 & This gene is involved in eating behavior. \\
\hline Tyrosine hydroxylase & TH & This gene plays a role in eating behavior. \\
\hline Thyrotropin-releasing hormone & TRH & This gene plays a role in eating behavior. \\
\hline $\begin{array}{l}\text { Transient receptor potential cation } \\
\text { channel, subfamily } \mathrm{M} \text {, member } 5\end{array}$ & TRPM5 & This gene plays an important role in taste transduction. \\
\hline
\end{tabular}

function" $\left(10^{-10}<P<10^{-3}\right)$, "hematopoiesis" $\left(10^{-10}<P<\right.$ $\left.10^{-3}\right)$, "lymphoid tissue structure and development" $\left(10^{-9}<\right.$ $\left.P<10^{-5}\right)$, "organismal survival" $\left(10^{-9}<P<10^{-4}\right)$, and "cell-mediated immune response" $\left(10^{-8}<P<10^{-5}\right)$. Each pathway is inclusive of related subcategories. For example, within nervous system development, the subcategories "development of cranial nerve" $(P<0.001)$ and "development of olfactory receptors" $(P<0.01)$ were found. There were 1,807 up-regulated genes that met the search criteria; 379 down-regulated genes were also considered.

One of the most novel aspects of both the current and previous analysis is the prominent role of "behavior" in neonatal oral feeding. Of all the statistically significantly upregulated pathways identified, genes associated with "behavior" were the most significant. Within this pathway, a subcategory entitled "feeding" was highlighted $\left(P<10^{-5}\right)$. Genes within this pathway were associated with "hyperphagia," "satiety," "obesity," and "weight gain” (Table 2). This novel pathway suggests that oral feeding in the newborn is neither merely reflexive nor solely dependent upon oral musculature and nervous system development. Rather, newborns rely, in part, on complex neurological signaling related to hunger, satiety, and energy expenditure for successful oral feeding. This makes biological sense. During the first year of life, a healthy term newborn will gain $200 \%$ or more of its birth weight. A preterm infant may gain upwards of $300 \%$ of his or her birth weight. The enormous amount of caloric intake required for such exponential growth is unique to the newborn period of the human lifespan. Thus, it is not surprising that the most statistically significant pathway in our analysis is related to biological mechanisms driving feeding behavior.

In the five most significantly up-regulated physiological pathways, new gene functions have also emerged. For example, in the prior study, the development of only the trigeminal nerve (Cranial Nerve $[\mathrm{CN}] \mathrm{V}$ ) was highlighted. At the time, we speculated that the development of this nerve, which provides motor innervation to the muscles of mastication, was essential for proper coordination of the suck- and swallow-reflex. In this updated analysis, we not only see upregulation of genes involved in the development of the trigeminal nerve, but also have identified genes involved in the developing facial (CN VII) and glossopharyngeal (CN IX) nerves (Table 3). Each of these nerves is known to be essential for safe coordination of swallowing with respiration, with CN VII innervating the sensory component of the facial mask, and CN IX providing sensory taste fibers to the posterior tongue. In addition, the subcategory "development of cranial nerve" was new to this analysis. Here, genes associated with the oculomotor (CN III) and vestibulocochlear (CN VIII) nerves were identified. Sensory development was also prominent in this targeted reanalysis of the data. There is an upregulation of genes involved in the developing eye $(P<0.01)$ and ear $(P<0.02)$, as well as the olfactory system $(P<0.01)$. Genes involved in olfactory receptor development were significantly upregulated as infants matured and learned to orally feed. This, too, is of great interest as emerging literature supports the role of the infant's olfactory system in the establishment of successful breastfeeding [11].

Genes involved in the developing nervous, skeletal and muscle systems were also highlighted in this analysis. There was a wide range of nervous system functions including the development of the brain, spine, central nervous system, neurons, neurites, and ganglions. Development of striated muscle ( $P=0.009$ ) was significantly upregulated over time, as was developing bone $(P=0.006)$ and cartilage $(P=$ $0.005)$. One of the limitations of this study is that neonatal subjects were followed over several weeks while in the NICU. During that time, there were global developmental processes occurring as the infants matured. However, by limiting salivary collection to five predefined feeding stages, there 
TABle 3: Cranial nerve development and morphogenesis $\left(10^{-3}<P<10^{-2}\right)$.

\begin{tabular}{|c|c|c|}
\hline Gene & Symbol & Relative biological functions \\
\hline \multicolumn{3}{|c|}{ Glossopharyngeal morphogenesis and development $\left(10^{-3}<P<10^{-2}\right)$} \\
\hline $\begin{array}{l}\text { Sema domain, immunoglobulin domain (Ig), short } \\
\text { basic domain, secreted, (semaphorin) 3D }\end{array}$ & SEMA3D & Nervous system development \\
\hline Plexin A4 & PLXNA4 & $\begin{array}{l}\text { Cranial nerve morphogenesis; facial nerve morphogenesis (CN } \\
\text { VII); glossopharyngeal nerve (CN IX) morphogenesis }\end{array}$ \\
\hline Homeobox D3 & HOXD3 & Glossopharyngeal nerve (CN IX) morphogenesis \\
\hline Homeobox B3 & HOXB3 & Glossopharyngeal nerve (CN IX) morphogenesis \\
\hline \multicolumn{3}{|c|}{ Survival and development of trigeminal nerve and ganglion $\left(10^{-3}<P<10^{-2}\right)$} \\
\hline B-cell CLL/lymphoma 2 & BCL2 & Neurodegeneration \\
\hline Glial cell derived neurotrophic factor & GDNF & $\begin{array}{l}\text { Axon guidance; neuron differentiation; neuron projection } \\
\text { development }\end{array}$ \\
\hline Neurturin & NRTN & Neuron projection development; axon guidance \\
\hline POU class 4 homeobox 1 & POU4F1 & Neuron differentiation \\
\hline POU class 4 homeobox 2 & POU4F2 & Trigeminal nerve development (CN V); suckling behavior \\
\hline $\begin{array}{l}\text { Solute carrier family } 6 \text { (neurotransmitter transporter, } \\
\text { creatine), member } 8\end{array}$ & SLC6A8 & Neurotransmitter transport \\
\hline Noggin & NOG & $\begin{array}{l}\text { Axon guidance; face morphogenesis; regulation of neuron } \\
\text { differentiation }\end{array}$ \\
\hline \multicolumn{3}{|c|}{ Cranial nerve development and morphogenesis $\left(P<10^{-3}\right)$} \\
\hline GLI family zinc finger 3 & GLI3 & $\begin{array}{l}\text { Optic nerve morphogenesis (CN II); palate development; } \\
\text { tongue development }\end{array}$ \\
\hline Cholinergic receptor, nicotinic, beta 2 (neuronal) & CHRNB2 & $\begin{array}{l}\text { Conditioned taste aversion; optic nerve morphogenesis; vestibu- } \\
\text { locochlear nerve development (CN VIII) }\end{array}$ \\
\hline Chromodomain helicase DNA binding protein 7 & CHD7 & $\begin{array}{l}\text { Face development; nose development; palate development; } \\
\text { sensory perception of sound; development in camera-type eye }\end{array}$ \\
\hline Hairy and enhancer of split 1, (Drosophila) & HES1 & $\begin{array}{l}\text { Oculomotor nerve development (CN III); pharyngeal system } \\
\text { development; auditory receptor cell differentiation and determi- } \\
\text { nation; cochlea development }\end{array}$ \\
\hline Neuropilin 2 & NRP2 & Semaphorin-plexin signaling pathway \\
\hline $\begin{array}{l}\text { Sema domain, immunoglobulin domain (Ig), short } \\
\text { basic domain, secreted, (semaphorin) 3D }\end{array}$ & SEMA3D & Nervous system development \\
\hline Homeobox B3 & HOXB3 & Glossopharyngeal nerve (CN IX) morphogenesis \\
\hline Homeobox D3 & HOXD3 & Glossopharyngeal nerve (CN IX) morphogenesis \\
\hline Plexin A4 & PLXNA4 & $\begin{array}{l}\text { Cranial nerve morphogenesis; facial nerve morphogenesis (CN } \\
\text { VII); glossopharyngeal nerve morphogenesis (CN IX) }\end{array}$ \\
\hline Thyroid hormone receptor, beta & THRB & Sensorineural hearing loss \\
\hline $\begin{array}{l}\text { v-erb-a erythroblastic leukemia viral oncogene } \\
\text { homolog } 4 \text { (avian) }\end{array}$ & ERBB4 & $\begin{array}{l}\text { Central nervous system morphogenesis and olfactory bulb } \\
\text { interneuron differentiation }\end{array}$ \\
\hline Homeobox D3 & HOXD3 & Glossopharyngeal nerve morphogenesis (CN IX) \\
\hline POU class 4 homeobox 1 & POU4F1 & Neuron differentiation \\
\hline Myosin VA (heavy chain 12 , myoxin) & MYO5A & Visual perception \\
\hline Sal-like 1 (Drosophila) & SALLI & $\begin{array}{l}\text { Olfactory bulb development and interneuron differentiation; } \\
\text { outer ear morphogenesis }\end{array}$ \\
\hline
\end{tabular}

was an opportunity to capture, in real-time, gene expression changes directly related to the attainment of safe oral feeding skills. These data support the complexity of oral feeding and further demonstrate how multiple processes involved in oral feeding may be monitored simultaneously in the newborn at the molecular level.

Of note, statistically significant down-regulated genes were related only to the developing hematological and lymphoid system. There was no obvious link between lymphoid and/or hematological development and oral feeding success that appeared when reviewing the down-regulated pathways and their associated subcategories. While it is possible that the development of the gastrointestinal immune system plays an important role in readiness to feed, our current understanding of these genes prohibits further speculation on their role, if any, in neonatal oral feeding skills.

This research demonstrates that with the advent of recent technical advances and high-throughput screening methods, 


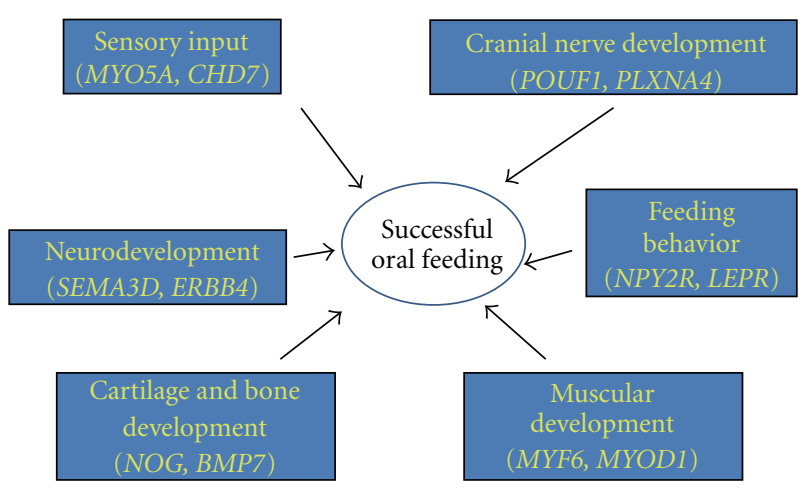

FIGURE 1: Through salivary gene expression analyses, genes involved in multiple developmental systems that are required for successful neonatal oral feeding can be monitored noninvasively and simultaneously. Combining gene targets, such as those identified, may ultimately lead to a noninvasive, objective, and accurate salivary diagnostic platform to determine readiness to orally feed in the newborn.

we are able to monitor, in real-time, normal and aberrant developmental processes occurring in the newborn from mere drops of saliva. Utilizing this information for the development of noninvasive salivary diagnostic panels is a novel and exciting aspect of translational medicine. Indeed, salivary diagnostic platforms are currently in development for adult patients with oral cancer, breast cancer, Sjögren's disease, pancreatic cancer, melanoma, nonsmall cell lung cancer, acute myocardial infarction, diabetes, and ovarian cancer [12-17]. These platforms are designed to be utilized at the bedside in order to give an accurate diagnosis within minutes with the use of point-of-care technology currently in development [18]. While these platforms are clinically important, none targets a neonatal or even a pediatric patient population. Yet neonates, with their limited blood volumes and clinical fragility, are the ideal patient population on which to apply this technology.

Compared to our prior analysis which examined global developmental processes in the newborn, the present study focused solely on genes believed to be involved in the attainment of successful oral feeding skills. This targeted analysis of the data is laying the foundation for the development of a neonatal oral readiness to feed salivary diagnostic platform. For example, our laboratory recently determined that salivary detection of one of the genes identified in this data set, neuropeptide Y2 receptor (NPY2R), a known hypothalamic regulator of feeding behavior, has a $95 \%$ positive predictive value for immature oral feeding skills [19]. A limitation to this biomarker is that if undetected in saliva, it is only $27 \%$ accurate in determining a safe and effective oral feeding pattern. However, as this work moves forward, other genes identified in this targeted analysis could be incorporated into a comprehensive platform, not only for the development of an accurate and objective diagnostic assay, but also to improve our understanding of aberrant feeding patterns in the newborn (Figure 1).

\section{Conclusion}

Neonatal salivary transcriptomic analysis provides noninvasive and objective information about the learning process of oral feeding in the newborn at the molecular level. These data further confirm the complexities of oral feeding and suggest that the development of feeding behavior is a novel and essential biological component to successful oral feeding. This research lays the foundation for the development of an objective, noninvasive assay for the determination of readiness to feed in the neonatal population in order to reduce morbidities and improve care and outcomes.

\section{Acknowledgments}

Funding for this research was provided by NICHD K08 HD 059819-03. The author declares that there are no conflict of interests.

\section{References}

[1] C. Lau, R. Alagugurusamy, R. J. Schanler, E. O. Smith, and R. J. Shulman, "Characterization of the developmental stages of sucking in preterm infants during bottle feeding," Acta Paediatrica, vol. 89, no. 7, pp. 846-852, 2000.

[2] K. Mizuno and A. Ueda, "Neonatal feeding performance as a predictor of neurodevelopmental outcome at 18 months," Developmental Medicine and Child Neurology, vol. 47, no. 5, pp. 299-304, 2005.

[3] M. Samara, S. Johnson, K. Lamberts, N. Marlow, and D. Wolke, "Eating problems at age 6 years in a whole population sample of extremely preterm children," Developmental Medicine and Child Neurology, vol. 52, no. 2, pp. e16-e22, 2010.

[4] A. L. Delaney and J. C. Arvedson, "Development of swallowing and feeding: prenatal through first year of life," Developmental Disabilities Research Reviews, vol. 14, no. 2, pp. 105-117, 2008.

[5] A. H. Jobe, "The new bronchopulmonary dysplasia," Current Opinion in Pediatrics, vol. 23, no. 2, pp. 167-172, 2011.

[6] J. Neu and W. A. Walker, "Necrotizing enterocolitis," New England Journal of Medicine, vol. 364, no. 3, pp. 255-264, 2011.

[7] J. A. Martin, M. J. K. Osterman, and P. D. Sutton, "Are preterm births on the decline in the United States? Recent data from the national vital statistics system," NCHS Data Brief, No. 39. May 2010, http://www.cdc.gov/nchs/data/databriefs/db39.htm.

[8] S. W. Tsai, C. H. Chen, and M. C. Lin, "Prediction for developmental delay on neonatal oral motor assessment scale in preterm infants without brain lesion," Pediatrics International, vol. 52, no. 1, pp. 65-68, 2010.

[9] M. M. Palmer, K. Crawley, and I. A. Blanco, "Neonatal oralmotor assessment scale: a reliability study," Journal of Perinatology, vol. 13, no. 1, pp. 28-35, 1993.

[10] J. L. Maron, K. L. Johnson, D. M. Rocke, M. G. Cohen, A. J. Liley, and D. W. Bianchi, "Neonatal salivary analysis reveals global developmental gene expression changes in the premature infant," Clinical Chemistry, vol. 56, no. 3, pp. 409-416, 2010.

[11] B. Schaal, "Mammary odor cues and pheromones. Mammalian infant-directed communication about maternal state, mammae, and milk," Vitamins and Hormones, vol. 83, pp. 83136, 2010. 
[12] Y. Li, M. A. R. S. John, X. Zhou et al., "Salivary transcriptome diagnostics for oral cancer detection," Clinical Cancer Research, vol. 10, no. 24, pp. 8442-8450, 2004.

[13] L. Zhang, H. Xiao, S. Karlan et al., "Discovery and preclinical validation of salivary transcriptomic and proteomic biomarkers for the non- invasive detection of breast cancer," PloS ONE, vol. 5, no. 12, Article ID e15573, 2010.

[14] S. Hu, J. Wang, J. Meijer et al., "Salivary proteomic and genomic biomarkers for primary Sjögren's syndrome,” Arthritis and Rheumatism, vol. 56, no. 11, pp. 3588-3600, 2007.

[15] L. Zhang, J. J. Farrell, H. Zhou et al., "Salivary transcriptomic biomarkers for detection of resectable pancreatic cancer," Gastroenterology, vol. 138, no. 3, pp. 949-957, 2010.

[16] K. Gao, H. Zhou, L. Zhang et al., "Systemic disease-induced salivary biomarker profiles in mouse models of melanoma and non-small cell lung cancer," PloS ONE, vol. 4, no. 6, Article ID e5875, 2009.

[17] C. S. Miller, J. D. Foley, A. L. Bailey et al., "Current developments in salivary diagnostics," Biomarkers in Medicine, vol. 4, no. 1, pp. 171-189, 2010.

[18] D. T. Wong, "Salivary diagnostics powered by nanotechnologies, proteomics and genomics," Journal of the American Dental Association, vol. 137, no. 3, pp. 313-321, 2006.

[19] J. L. Maron, K. L. Johnson, J. A. Dietz, M. L. Chen, and D. W. Bianchi, "Neuropeptide Y2 Receptor (NPY2R) expression in saliva predicts feeding immaturity in the premature neonate," PloS ONE, vol. 7, Article ID e37870, 2012. 


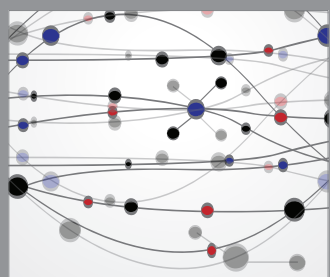

The Scientific World Journal
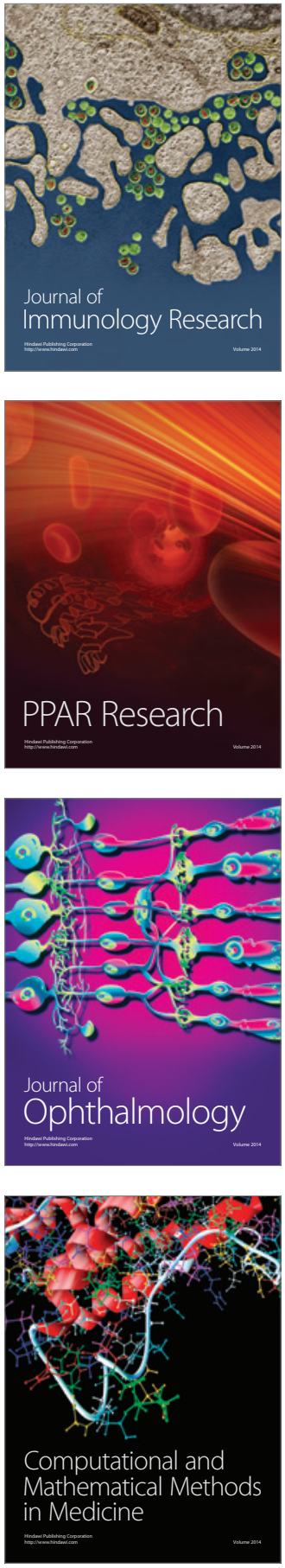

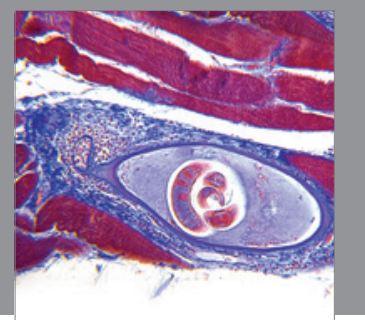

Gastroenterology

Research and Practice
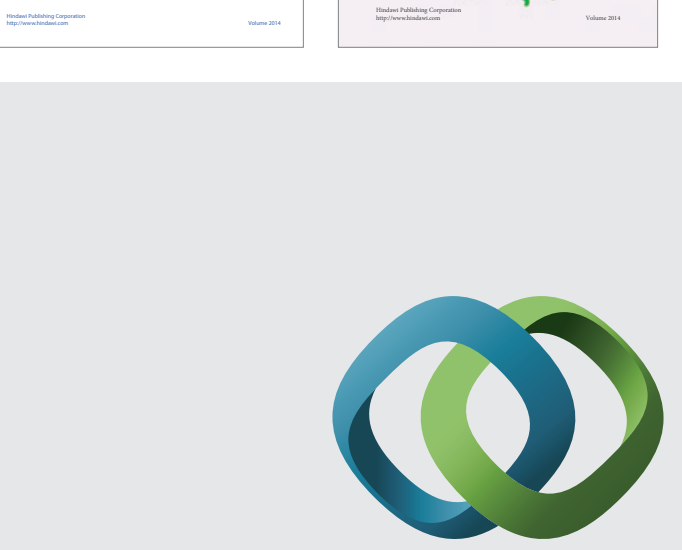

\section{Hindawi}

Submit your manuscripts at

http://www.hindawi.com
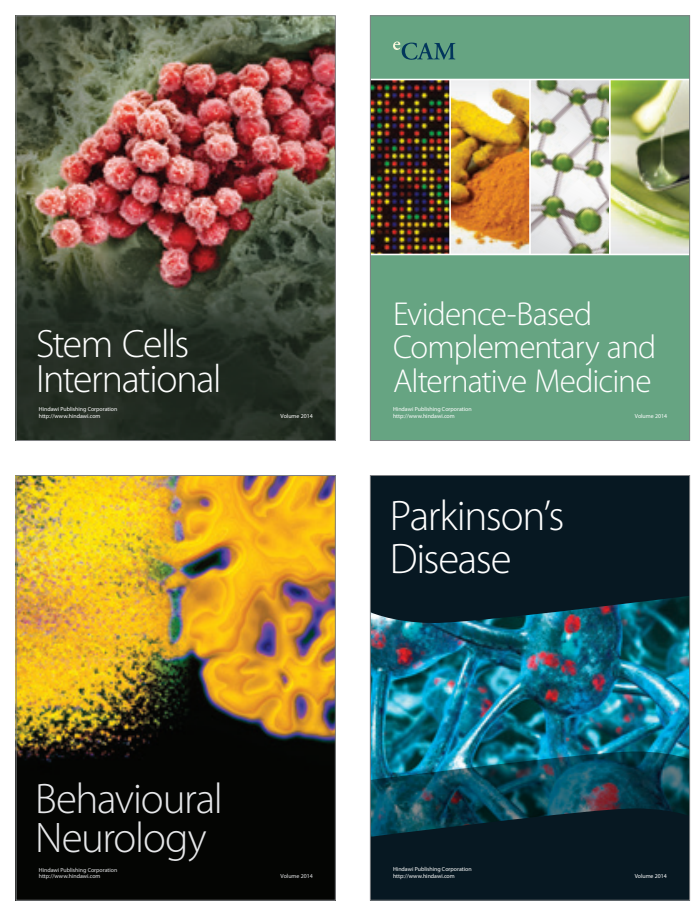

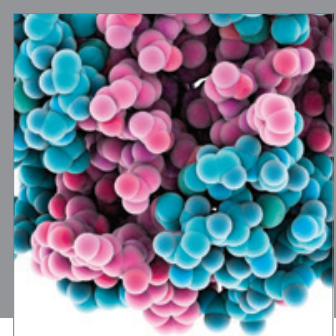

Journal of
Diabetes Research

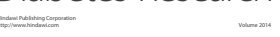

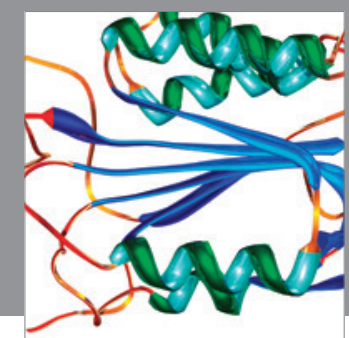

Disease Markers
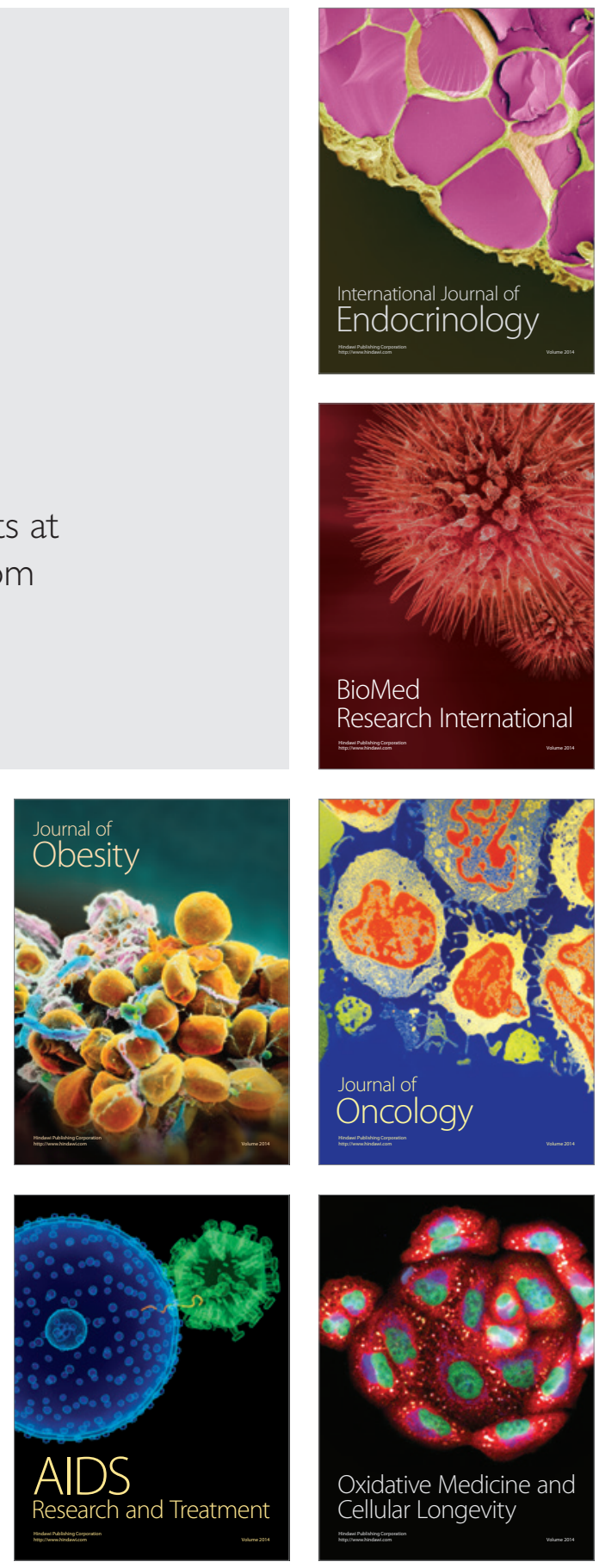